\title{
Tamanho do tubérculo-semente de batata não interfere na manifestação da murcha bacteriana
}

\author{
Carlos A Lopes'; Maurício Rossato² \\ ${ }^{1}$ Embrapa Hortaliças, C. Postal 218, 70351-970 Brasília-DF, clopes@cnph.embrapa.br; 2UFV, 36570-000 Viçosa-MG
}

\section{RESUMO}

A batata-semente é comercializada no Brasil em diferentes tamanhos, conforme determinação do MAPA, variando do tipo 0 (zero), com tubérculos acima de $60 \mathrm{~mm}$, até o tipo V, com tubérculos menores que $23 \mathrm{~mm}$. Neste trabalho, foi avaliado o efeito do tamanho do tubérculo da batata-semente na manifestação da murcha bacteriana nas cultivares Agata, BRS Ana, Asterix e Bintje, em campo naturalmente infestado com Ralstonia solanacearum, em Brasília-DF. Foram usados tubérculos pequenos, médios e grandes, com aproximadamente 30, 50 e 90 mm em média, tamanhos correspondentes respectivamente aos tipos IV, II e 0 das normas do MAPA. Diferenças significativas quanto à incidência da doença foram encontradas entre cultivares: BRS Ana e Asterix não diferiram entre si e foram mais resistentes que Agata e Bintje que, por sua vez, tampouco diferiram entre si. As diferenças entre tamanhos de tubérculos e as interações entre cultivar e tamanho de tubérculos não foram significativas. Portanto concluiu-se que o tamanho de tubérculos dentro dos limites avaliados neste trabalho, não interferiu na manifestação da doença em testes de avaliação para resistência à murcha bacteriana.

Palavras-chave: Solanum tuberosum, Ralstonia solanacearum, batata-semente, murchadeira.

\begin{abstract}
Potato seed tuber size does not interfere with the incidence of potato bacterial wilt

Potato seed tubers in Brazil are commercialized in different sizes as determined by the Ministry of Agriculture, Livestock and Food Supply. The sizes are classified in types, which vary from type 0 (zero), tubers above $60 \mathrm{~mm}$, up to type V, tubers below $23 \mathrm{~mm}$. In this work, we evaluated the influence of seed tuber size on the incidence of bacterial wilt on cultivars Agata, BRS Ana, Asterix, and Bintje, grown in a field naturally infested with Ralstonia solanacearum, in Brasilia, Brazil. We used small, medium and large tubers, measuring in average 30, 50 and $90 \mathrm{~mm}$, which correspond respectively to types IV, II and 0 according to the Brazilian legislation. Significant differences in bacterial wilt incidences were detected among cultivars: BRS Ana and Asterix did not differ from each other and were more resistant than Agata and Bintje, which formed a statistically homogeneous pair. Differences on the seed tuber size and interactions between cultivars and tuber size were not significant. Therefore, the seed tuber size, within the limits covered in this paper, have no effect on disease incidence in field screening for potato resistance to the bacterial wilt.
\end{abstract}

Keywords: Solanum tuberosum, Ralstonia solanacearum, seed potato, brown rot.

(Recebido para publicação em 7 de junho de 2010 ; aceito em 15 de maio de 2011)

(Received on June 7, 2010; accepted on May 15, 2011)

$\mathrm{O}$ tamanho do tubérculo usado no plantio é fator determinante no custo de produção e na produtividade da batata (Solanum tuberosum L). Por isso, de acordo com as normas do Ministério da Agricultura, Pecuária e Abastecimento (MAPA), a batata-semente seja ela básica, registrada ou certificada, é tipificada em categorias, baseadas em seu tamanho: tipo I (tubérculos entre 50 e $60 \mathrm{~mm}$ ), tipo II (entre 40 e $50 \mathrm{~mm}$ ), tipo III (entre 30 e $40 \mathrm{~mm}$ ), tipo IV (entre 23 e $30 \mathrm{~mm}$ ) e tipo $\mathrm{V}$ (menores que 23 mm) (MAPA, 1987). O tipo 0 (acima de $60 \mathrm{~mm}$ ) existe nas classes básica e registrada, mas, na classe certificada, o registro só é feito para a instalação de campos do próprio produtor, ou seja, não é comercializado formalmente. Também conforme a mesma norma, "a mistura de tipos e tamanhos dentro da mesma embalagem não deverá exceder 5\%".

A questão de tamanho da batata-semente é relevante para o manejo da cultura, especialmente quando se leva em consideração os diferentes sistemas de cultivo relativos à produção de batata-consumo e batata-semente nas diferentes regiões do Brasil. Mesmo assim tem recebido pouca atenção por parte da pesquisa, o que foi evidenciado pela escassa literatura disponível neste tema. De acordo com Filgueira (1999), a decisão do produtor de plantar tamanhos maiores ou menores de batata-semente é de natureza econômica. Como a batata-semente é adquirida por volume e peso (caixa de $30 \mathrm{~kg}$ ), é mais vantajoso para o produtor adquirir tubérculos menores, pois assim adquire maior número de unidades de plantio. De modo geral, tubérculos maiores produzem maior nú- mero de hastes e plantas mais vigorosas por disporem de maior número de gemas e maior volume de reservas, o que garante um desenvolvimento inicial mais vigoroso da planta. Assim, mantendo-se o mesmo espaçamento, o plantio de tubérculos de tamanhos maiores resulta em maior densidade de hastes, maior número de tubérculos formados, mas de menor tamanho, o que é desejável para a produção de batata-semente (Filgueira, 1999).

A relação entre tamanho de tubérculos-semente e produção comercial de batata foi avaliada por vários autores, que normalmente referiam-se ao peso e não à medida dos tubérculos. Boock \& Nóbrega (1962) e Caron \& Baldanzi (1965) obtiveram maiores produções com tubérculos-sementes maiores, embora, por questões econômicas, a recomen- 
dação para o plantio seja de tubérculos com cerca de $50 \mathrm{~g}$, mesmo valor recomendado por Dias (1962). Guimarães \& Liberal (1955) concluíram, após cinco experimentos com tubérculos-semente variando de 10 a 140 g, que a influência do tamanho do tubérculo-semente varia de acordo com a época de plantio, mas a produção é diretamente proporcional ao peso dos tubérculos plantados. Silva et al. (1988) observaram, em três anos de estudo, que tubérculos maiores favorecem emergência mais rápida e desenvolvimento vegetativo mais precoce, embora concluam que o tamanho da batata-semente tem pouca influência no rendimento econômico, desde que o espaçamento seja ajustado, com lucro máximo obtido pelo uso do tipo III. Da mesma forma, Sonnenberg \& Filgueira (1979) demonstraram que não há vantagem agronômica em se plantar tubérculos graúdos e recomendam tubérculos de 20 a $40 \mathrm{~g}$.

Em estudo recente, Müller et al. (2010) avaliaram a dormência e a dominância apical em três tamanhos de tubérculos (inferior a $35 \mathrm{~mm}$, entre 35 e $45 \mathrm{~mm}$ e superior a $45 \mathrm{~mm}$ ) de três genótipos de batata. Concluíram que tubérculos de diferentes tamanhos têm diferentes idades fisiológicas e que tubérculos menores apresentaram maior período de dormência.

Uma das dificuldades de relacionar tamanho da batata-semente com produção é o fato de que tubérculos menores têm maior probabilidade de estarem contaminados por vírus, já que um dos efeitos das viroses sobre a batata é a redução do tamanho dos tubérculos, conforme constatado desde há muito por Guimarães \& Liberal (1955). Assim, no caso de tubérculos menores, se infectados, o efeito do tamanho do tubérculo sobre a produção fica confundido com o efeito da virose, mascarando os resultados.

Ainda em relação ao tamanho das unidades de plantio, o corte de batata-semente graúda é indicado em algumas situações para o estado de Santa Catarina como uma alternativa para aumentar rendimento e reduzir custos (Silva et al., 1988; Epagri, 2002), embora Sampaio Filho \& Drummond (1959) e Filgueira (1999) chamem a atenção dos riscos de contaminação por patógenos em unidades cortadas.

Em função de existirem vários tamanhos de batata-semente, há que se considerar a combinação da cultivar, do espaçamento e do tamanho dos tubérculos para se obter um número adequado de hastes por superfície. $\mathrm{O}$ número de ramas (hastes) por hectare recomendado para o plantio comercial de batata em países europeus está em torno de 150.000 (Boller et al., 2003), número bem próximo daquele considerado ideal na agricultura paulista, de 110.000 a 150.000 hastes por hectare (Filgueira, 1999). Para a produção de batata-semente, a densidade de plantas tem que ser maior para possibilitar a produção de maior número de tubérculos de tamanho adequado para o plantio.

A murcha bacteriana, causada por Ralstonia solanacearum (Smith 1896) Yabuuchi et al. 1995, é uma das principais doenças da batata em regiões de clima tropical e subtropical. Quando as condições ambientais são favoráveis à doença, as perdas podem passar de 50\% (Lopes, 2005). O controle da murcha bacteriana é muito difícil e a recomendação de controle baseia-se em um conjunto de medidas preventivas, sobressaindo-se a escolha da área, o preparo do solo, o manejo da irrigação e o trânsito de máquinas na lavoura, entre outras (Lopes, 2005).

O objetivo deste trabalho foi avaliar se o tamanho dos tubérculos-sementes de batata afeta a manifestação da murcha bacteriana.

\section{MATERIAL E MÉTODOS}

O experimento foi conduzido durante os meses de junho a agosto em campo naturalmente infestado com a raça 1 , biovar 1 de $R$. solanacearum, localizado na fazenda experimental da Embrapa Hortaliças, em Brasília-DF. Tubérculos de semente básica das cultivares Agata, BRS Ana, Asterix e Bintje, de três tamanhos (pequeno, médio e grande), foram separados a partir de lotes produzidos em Canoinhas-SC. Os tubérculos pequenos apresentavam em média $30 \mathrm{~mm}$ de diâmetro, os médios aproximadamente $50 \mathrm{~mm}$ e os grandes aproximadamente $90 \mathrm{~mm}$, tamanhos correspondentes aos tipos IV, II e 0, respectivamente, das classes básica e registrada, conforme Portaria $\mathrm{N}^{\circ} 154$, de 23/07/1987, do MAPA (Pereira \& Daniels, 2003).

O delineamento experimental consistiu de parcelas subdivididas com dez plantas cada, sendo as cultivares consideradas subparcelas, em três repetições. O preparo e a correção de solo, adubação e outros tratos culturais foram realizados conforme sistema de produção seguido na Embrapa Hortaliças. A incidência da doença foi avaliada semanalmente por seis semanas, considerando-se a planta como murcha quando mais de 50\% das ramas apresentavam o sintoma.

Os tratamentos tamanho de tubérculos (TT), cultivares (CB) e interação TT x CV tiveram suas médias comparadas pelo teste de Tukey $(\mathrm{p}<0,05)$ após a análise de diferenças significativas pelo teste de F, realizado pelo SISVAR (UFLA, 2007). A variável de trabalho foi a área abaixo da curva de progresso da doença (AACPD), conforme fórmula gentilmente fornecida pela UFV. A utilização da AACPD é vantajosa por considerar todo o período de evolução da doença, para cada cultivar e cada tamanho de tubérculo.

\section{RESULTADOS E DISCUSSÃO}

A evolução da murcha bacteriana no campo experimental foi rápida, acelerada especialmente após a realização da amontoa, e ocorreu de forma bastante homogênea (Figura 1). As diferenças entre tamanhos de tubérculos e as interações entre cultivar e tamanho de tubérculos não foram significativas. Diferenças significativas quanto à incidência da doença foram encontradas somente entre cultivares, indicando um progresso mais lento da doença nas cultivares Asterix e BRS Ana, mais evidente na primeira metade do ciclo da cultura (Figura 2).

A ausência de efeito do tamanho de tubérculo na produção e na manifestação da murcha bacteriana pode ser explicada, pelo menos em parte, pelo fato da planta de batata tornar-se independente da batata-mãe cerca de cinco a seis semanas após o plantio (Filgueira, 1999). A partir daí, o sistema radicular 




Figura 1. Curvas de progresso da murcha bacteriana em quatro cultivares de batata plantadas em campo naturalmente infestado com Ralstonia solanacearum (disease progress curves of bacterial wilt on four potato cultivars grown in a field naturally infested with Ralstonia solanacearum). Brasília, Embrapa Hortaliças, 2008.

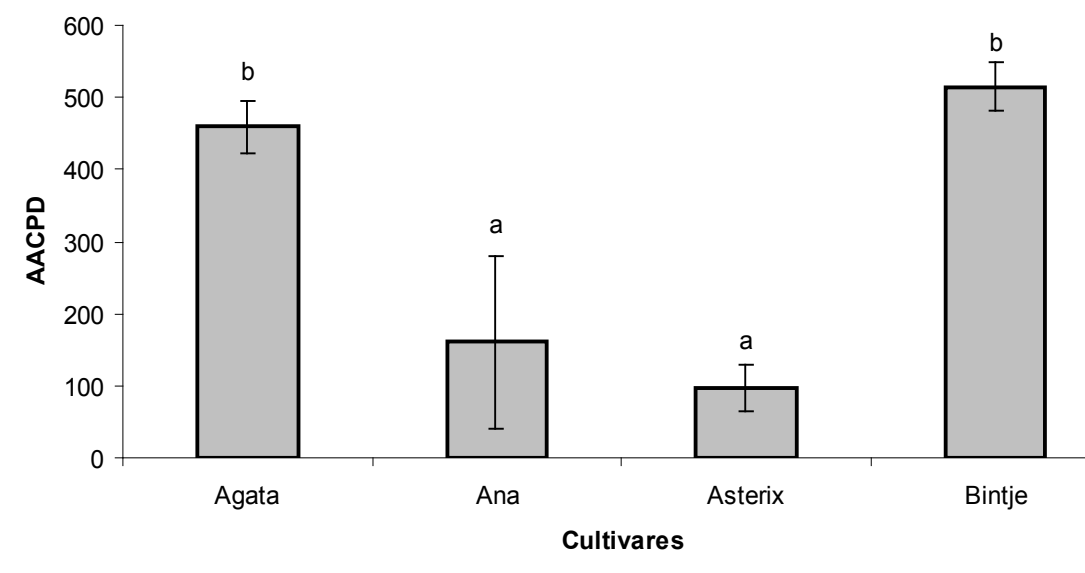

Figura 2. Área abaixo da curva de progresso da doença (AACPD) em quatro cultivares de batata plantadas em campo naturalmente infestado com Ralstonia solanacearum (area under the Disease Progress Curves (AUDPC) in four potato cultivars grown in a field naturally infested with Ralstonia solanacearum). Brasília, Embrapa Hortaliças, 2008.

se estabelece e torna-se suficiente para absorver a água e os nutrientes disponíveis no solo. Como a penetração de $R$. solanacearum se dá pelas raízes emitidas pelos brotos individualmente, poder-se-ia esperar que plantas derivadas de tubérculos maiores fossem mais afetadas ao serem mais rapidamente infectadas, já que apresentam brotação mais rápida, conforme relatado por Müller et al. (2010). Porém, não se descarta a possibilidade de que a manifestação da doença em plantas derivadas de tubérculos maiores possa ter sido afetada pelo maior vigor das plantas derivadas desses tubérculos. Estudos recentes de Streck et al. (2009) corroboram essa afirmativa ao concluírem que o tamanho do tubérculo não afetou o filocrono ou o intervalo de tempo entre a emissão de duas folhas sucessivas da planta de batata, ou seja, o tamanho do tubérculo-semente parece afetar o desenvolvimento das plantas somente nos primeiros dias do ciclo da cultura.

Assim, concluiu-se que a escolha do tamanho de tubérculos, dentro dos limites avaliados neste trabalho, não tem efeito quando se trata de avaliação de batata para resistência à murcha bacteriana.

\section{AGRADECIMENTOS}

CA Lopes e M Rossato são bolsistas do CNPq e CAPES, respectivamente.

\section{REFERÊNCIAS}

BOLLER W; DALLMEYER AU; KLEIN VA. 2003. Preparo do solo, plantio e amontoa. In: PEREIRA AS; DANIELS J (eds). O Cultivo da Batata na Região Sul do Brasil. Brasília: Embrapa Informação Tecnológica. p.177-201

BOOCK OJ; NÓBREGAAS. 1962. Influência do tamanho do tubérculo-semente na brotação e produção da batatinha. Olericultura 2: 38-51.

CARON AG; BALDANZI G. 1965. Influência do peso do tubérculo-semente sobre a produção da cultura. Revista de Agricultura 40: 43-47.

DIAS CAC. 1962. Batata-semente. In: Cultura da Batata. DATE. São Paulo: Instruções Técnicas 7: 26-31.

EPAGRI. 2002. Sistemas de produção para batata-consumo e batata-semente em Santa Catarina. Florianópolis.124 p.

FILGUEIRA FAR. 1999. Práticas culturais adequadas em bataticultura. Informe Agropecuário 20: 34-41.

GUIMARÃES FF; LIBERAL MT. 1955. Influência do peso dos tubérculos-semente no rendimento da batata americana. Agronomia Sulriograndense 2: 3-15.

LOPES CA. 2005. Murchadeira da batata. Itapetininga: ABBA. 66p.

MÜLLER DR; BISOGNIN DA; MORIN GR; GNOCATO FS. 2010. Dormência e dominância apical de diferentes tamanhos de tubérculos de batata. Ciência Rural 40: 2454-2459.

MAPA - Ministério da Agricultura, Pecuária e Abastecimento. 1987. Portaria $N^{\circ} 154$, de 23 de julho de 1987. Disponível em http:// extranet.agricultura.gov.br/sislegis/action/ detalhaAto.do?method=consultarLegislaca oFederal. Acessado em fevereiro de 2011).

PEREIRAAS; DANIELS J. (eds) 2003. O Cultivo da Batata na Região Sul do Brasil. Brasília: Embrapa Informação Tecnológica. 567 p.

SAMPAIO FILHO AV; DRUMMOND AO. 1959. Influência do peso do tubérculo-semente sobre a produção da batatinha. Boletim Agrícola do Departamento de Produção Vegetal 7: 72-73.

SILVA ACF; MÜLLER JJV; AGOSTINI I; BRAGA JÚNIOR RLC; MIURA L. 1988. Efeito do espaçamento e tamanho de tubérculos-semente inteiros e cortados no rendimento da batata consumo. Horticultura Brasileira 6: 27-29.

SONNENBERG PE; FILGUEIRA FAR. 1979. Efeito do peso do tubérculo-semente, na produção de batata (Solanum tuberosum $L$.), cultivar Spunta, em duas épocas de plantio. Goiânia: Universidade Federal de Goiás. 17p. (Horticultura Informações Técnicas)

STRECK NA; PAULA FLM; DELLAI J; BISOGNIN DA; PAULAAL. 2009. Filocrono em batateira afetado pelo tamanho do tubérculo-semente e pela época de cultivo. Bragantia 137-143. 